Article

\title{
Does Fashionization Impede Luxury Brands' CSR Image?
}

\author{
Béatrice Parguel $1, * \mathbb{D}$, Thierry Delécolle ${ }^{2}$ and Aïda Mimouni Chaabane ${ }^{3}$ \\ 1 CNRS, DRM [M-LAB], Université PSL, Université Paris-Dauphine, 75016 Paris, France \\ ISC Paris, 75017 Paris, France; thierry.delecolle@iscparis.com \\ 3 THEMA, Université de Cergy-Pontoise, 95000 Cergy, France; aida.mimouni@u-cergy.fr \\ * Correspondence: beatrice.parguel@dauphine.psl.eu; Tel.: +33-1-44-05-4454
}

Received: 3 December 2019; Accepted: 3 January 2020; Published: 6 January 2020

\begin{abstract}
To sustain their growth worldwide, luxury brands are increasingly adopting the codes of fast fashion. They continually introduce new designs that move quickly from the catwalk to stores to stay on-trend, resulting in short and constantly renewed collections. But does this fashionization impede luxury brands' Corporate Social Responsibility (CSR) image? This article investigates this question building on the ephemerality-scarcity dual-route model. Findings from a first experiment involving a fictitious luxury brand show that fashionization increases both perceptions of ephemerality (negative route) and scarcity (positive route), with opposing resulting effects on the brand's CSR image. Extending these results to a real-life luxury setting, findings from a second experiment show that the influence of fashionization on the brand's CSR image is only mediated by the positive scarcity route. This study provides a number of noteworthy theoretical insights and relevant managerial implications for luxury managers involved in CSR communication.
\end{abstract}

Keywords: fashionization; luxury brand; corporate social responsibility; scarcity; ephemerality

\section{Introduction}

Ontologically, luxury is not the very opposite of sustainability. "When you buy a luxury product, you think it will last [but] there is a kind of modification of luxury today, as fashion is now seizing the territory of luxury" [1]. Fashionization in the luxury sector takes many forms. Luxury brands take more direct inspiration from streetwear designers and influencers, such as Virgil Abloh, who was recently appointed Louis Vuitton's new artistic director of menswear. They introduce an increasing number of pre-fall, cruise, and resort collections in addition to the traditional two-season calendar (Spring/Summer and Autumn/Winter). They launch several limited editions (e.g., Chanel's Métiers d'Art collection and runway bags) and implement the see now/buy now concept (invented by Burberry) that makes products available right after the show. This fashionization, where luxury brands are positioning product lines closer to fast-fashion industry codes and managing them accordingly, allows a rapid response to emerging trends and fashion consumer demands. It also fuels a seemingly mass exclusivity through a continual and rapid turnover. In the end, creating permanent visibility in the media, and especially in the social media, fashionization aims at increasing volumes and profit [2].

This new fashionization trend in the luxury sector could compromise luxury brands' corporate social responsibility (CSR) image because fashion, and especially fast-fashion, appear unsustainable by nature [3]. Fueling a permanent desire for renewal, fashion consists in offering products that are popular and accepted by a particular social group for a period of time but remain subject to rapid and frequent changes [4]. Furthermore, thriving on fast cycles, fast fashion encourages indulgent consumption and rapid disposition [5]. As such, fashion suggests systematic and planned obsolescence. In addition, significant environmental problems have been experienced by the fashion industry including the 
intense use of chemical products, transport-related energy consumption and emissions linked to the relocation of production sites in Asia, and tremendous difficulties in greening the supply chain [6]. Common wisdom would therefore consider that the fashionization of luxury brands could make them appear as ephemeral, hence less associated with CSR principles. In the meantime, consumers do not spontaneously apply the idea of sustainability when it comes to fashion [2]. In addition, the fashionization of luxury brands also relies on craftsmanship, as well as original and unique creations [7], which may also make them appear as virtually scarcer, hence more associated with CSR principles [8]. But could this alternative mediating route, via perceived scarcity, compensate for the expected negative mediating route, via perceived ephemerality, to explain the influence of fashionization on CSR image? To answer this open question, the objective of this research was to investigate whether fashionization impedes luxury brands' CSR image, hence confirming common wisdom, or not.

The impact of fashionization on luxury brands' CSR image is a question of critical importance as luxury brands have made big investments in CSR programs in the last decade (e.g., in 2016, LVMH launched its LIFE 2020 program to strengthen its "commitment to making protection of the environment a key growth driver"; in 2017, Kering launched its 2025 strategy to craft more sustainable luxury and followed this up in 2018 with the publication of environmental and social standards for manufacturing processes and raw materials; sources: https://www.lvmh.com/group/lvmh-commitments/, http:// www.kering.com/en/sustainability). This greater emphasis on sustainability has been driven by new forces such as increasing customer demand for sustainable business practices, new regulations and support from public policy makers in the context of a new international momentum, the recognition of sustainability as a financial lever, and pressure associated with the future availability and price of raw materials $[9,10]$. This question is all the more important since fashionization has made luxury brands more visible in the media and more attractive targets for sustainable development activists and watchdog groups [11,12].

To answer this question, we drew on the emergent body of research on the compatibility between luxury and CSR $[8,13,14]$, and conducted two experiments. Considering a fictitious luxury brand, and in line with the seminal research we drew on from [8], a first experiment $(N=94)$ shows that both perceived ephemerality and scarcity mediate the influence of fashionization on CSR image. Extending these results to a real luxury brand, a second experiment $(N=98)$ shows that only perceived scarcity mediates the influence of fashionization on CSR image. These findings make two main contributions. First, and running counter to common wisdom, they show that fashionization is compatible with luxury brands' CSR. Second, they support the ephemerality-scarcity dual-route model as a relevant conceptual framework to study the compatibility between luxury and CSR. From these contributions, we derived concrete practical recommendations for CSR communication that is appropriate to the fashionization currently at work in the luxury sector.

\section{Theoretical Framework and Hypotheses}

\subsection{Luxury and CSR Image}

CSR refers to organizations' strategies and campaigns aimed at respecting ethical values, people, community, and the environment [15]. Focused on excellence [16], luxury houses have been working for a while to improve the sustainability of their business practices but remained relatively silent about this till recently $[12,17]$. With the rise of the luxury industry's CSR agenda, recent research has shown an increasing interest in the question of the compatibility between luxury and CSR $[8,13,14,18,19]$, but has not yet reached any clear consensus.

On the one hand, luxury houses are logically inclined to avoid possible societal and environmental harms related to their activity [11]. They naturally reduce the use of natural resources of limited availability and restrict the number of luxury items available, as maintaining scarcity helps create desirability [20]. By generating higher margins, they can easily finance environmental and social 
initiatives, making luxury intrinsically sustainable [21]. Going further, a nascent body of research shows that luxury brands can build effective CSR associations through brand, product, and message-related features $[8,17,22,23]$. For example, inconspicuous responsible luxury brands have more favorable CSR associations than conspicuous brands, especially among consumers displaying low to modest self-identity [22]. The compatibility between luxury and CSR is also perceived as higher among consumers who define luxury as extreme quality (vs. expensive or rare) [17]. In addition, when luxury products are long-lasting (e.g., jewelry vs. clothing), scarcity (i.e., a combination of rare raw materials, a small number of pieces, a high price, and exclusive distribution) is perceived as more socially responsible than wider availability [8]. Finally, an environmental claim that emphasizes enhancement of a "green" personal social status has been found to trigger better product evaluations in a luxury context [23].

On the other hand, consumers buying luxury items are not particularly or intentionally attentive to sustainability and tend to focus instead on brand, quality, prestige, product attributes, self-image, and price $[17,24,25]$. Some may even respond negatively to the use of recycled materials in luxury goods [13], highlighting a contradiction between luxury, seen as superficial and designed to exclude people, and sustainability $[17,18]$. CSR communication that refers to a concept of self-transcendence (i.e., protecting the welfare of all) could even conflict with the self-enhancement concept (i.e., dominance over people and resources) inherent to most luxury brands, resulting in lower appeal [14].

The above discussion shows that a critical issue when studying the compatibility between luxury and CSR is identifying the psychological processes that drive brand CSR image. This latter consists of consumers' perceptions about the brand's commitment to CSR principles [26,27]. As any type of brand association, CSR brand image results from consumers' indirect exposure to CSR-relevant information, controlled or not by the company owning the brand (e.g., advertising, word-of-mouth, product crisis), but also from consumers' direct experience with products [28]. In this research, we specifically focused on the influence of the fashionization of luxury, as it can be inferred from the brand's products that are displayed on its website, on the brand's CSR image. Ultimately, our ambition was to investigate whether, as common wisdom, the fashionization of luxury impedes the development of a positive CSR image for luxury brands. To do so, we drew on the potential influence of fashionization on perceptions of ephemerality and scarcity that have already appeared as relevant boundary conditions to explain luxury brands' CSR image $[8,18]$.

\subsection{Fashionization of Luxury and the Ephemerality Route}

Referring to the Wabi-Sabi Japanese world view, ephemerality can be defined as a transient, evanescent, impermanent, incomplete, and imperfect state [29]. Consequently, perceived ephemerality refers to the perception of the enduring or more transitory character of products [8].

Products can be perceived as more or less ephemeral depending on their product category (e.g., enduring jewelry vs. transitory clothing) [8]. Furthermore, various marketing tactics can also enhance the perception of ephemerality, such as pop-up stores, short-lived promotional events, or fashionization. As it relies on new styles and designs that move quickly from the catwalk to stores to stay on-trend and are constantly revisited, fashionization conveys the perception that products are only transitory. Contrary to more classical luxury that is inherently perceived as timeless, fashion-based luxury will inherently go out of fashion since frequent change and newness are the very essence of fashion $[19,30]$. As such, fashionization of luxury brands should increase their perceived ephemerality.

In turn, ephemerality carries negative connotations in luxury consumption, as it suggests excess and waste, with consumers constantly demanding new products designed for short-term consumption [31]. Due to the implication of planned obsolescence [32], ephemeral fashion collections have fueled increasing criticism in recent years for their environmental and social costs, leading to the emergence of the "slow fashion" movement promoting sustainable fashion solutions [33]. In particular, the slow fashion movement wants to slacken the pace of new collections and return to the traditional two collections per year [34]; the implicit accusation that the rapid turnover makes 
ephemeral fashion collections non-sustainable is clear. Consequently, brands whose products are perceived as ephemeral should be associated with a poor CSR image. As an alternative rationale, ephemeral fashion collections also suggest "glitz and glamour" and are more closely associated with immediate and hedonic consumption [29] (p.53) that nurtures self-enhancement, which has been suggested to conflict with CSR principles [14]. In the end, we expected to find that the fashionization of a luxury brand erodes brand CSR image, due to ephemerality perceptions.

Hypothesis 1 (H1). Fashionization triggers perceived ephemerality, which damages brand CSR image.

\subsection{Fashionization of Luxury and the Scarcity Route}

As a ubiquitous phenomenon in consumers' life in general [35], scarcity is particularly relevant in the luxury domain. With its use of scarce and precious raw materials and human expertise that naturally limit production capacity, "luxury implies scarcity" [36] (p.316). To preserve their appeal while expanding into a broader market hence reducing objective scarcity, luxury brands have used virtual rarity tactics to contribute to perceived scarcity, namely the perception of the rare character and limited availability of products [37]. Techno-rarity tactics involve continuous innovation and improvement of luxury products. Information-based rarity tactics entail selective or even exclusive distribution, advertising in the glossy media, or preferring public relations approaches over advertising [38]. Last, but not least, limited-edition rarity tactics involve production of special, temporary series that voluntarily limit the availability of luxury goods [37] (p.13).

The fashionization of luxury fuels perceived scarcity in different ways. As it is based on constant style and design innovation, it primarily concerns luxury goods that are always new and original, which suggests a form of techno-rarity. To a certain extent, consumers who do not buy those items right away will not be able to get them later [2]. As such, products are often only bought and worn by a small group of very self-confident consumers, whereas traditional products suggest a homogeneous "classic" style which can be adopted by most consumers. This also enhances perceived scarcity. In addition, fashionization often involves collaborations with the artistic world, through limited editions with famous avant-garde artists and multiple small-capsule collections [39], which lie on both information-based and limited-edition rarity tactics. Consequently, the fashionization of the luxury brand should increase its perceived scarcity.

Perceived scarcity should in turn have a positive influence on CSR image as sustainability is essentially rooted in scarcity. On the production side, scarce products consume fewer natural resources of limited availability and are therefore better aligned with the aim of renewal of natural resources $[8,40]$. Scarce products also induce fewer supply chain activities and are therefore intrinsically more sustainable than masstige products, which are produced in larger volumes [20]. On the demand side, since scarcity restricts availability, scarce products convey the idea of frugality [8] and a more responsible consumption of luxury that prioritizes product quality and originality over quantity. In the end, perceived scarcity may provide an alternative route to building a positive CSR image. Therefore, we expected to find that the fashionization of a luxury brand enhances brand CSR image, due to scarcity perceptions.

Hypothesis 2 (H2). Fashionization triggers perceived scarcity, which enhances brand CSR image.

The conceptual model, derived from the above discussion, is depicted in Figure 1. 


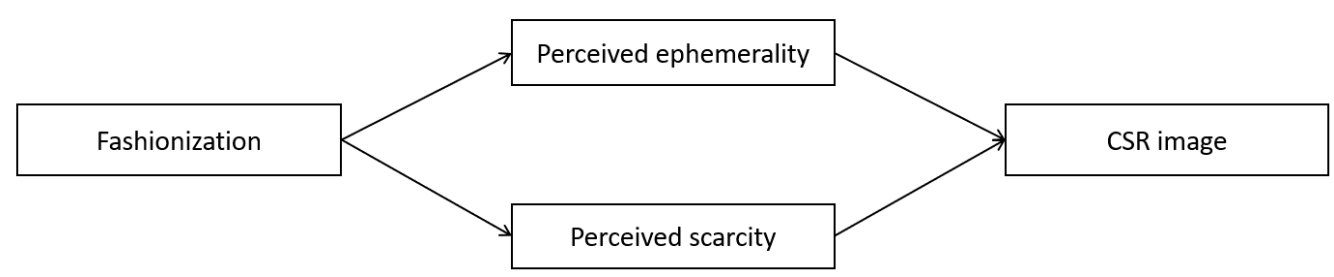

Figure 1. Model of the effect of fashionization on brand CSR image.

\section{Materials and Methods}

Two experiments were conducted to test the hypotheses. They both took the form of an online survey of consumers' perceptions of a luxury personal goods brand, based in France. Aimed at testing the hypotheses in a controlled setting, Study 1 used a fictitious luxury brand, Clodine. As such, Study 1 used the same experimental setting as the research we mainly drew on from a theoretical point of view [8] and allowed a replication test, while controlling for the influence of the experimental setting. Study 2 referred to the real luxury brand Louis Vuitton and aimed at enhancing the external validity of the findings derived from Study 1. The stimuli for both studies consisted of pictures of one (Study 1) or more (Study 2) handbags on a specific page of the brand website. The reason for choosing handbags was market-driven: the market for personal luxury goods is seen as the "core of the core" by experts, and handbags form the largest accessory segment, accounting for $\$ 44$ billion of retail sales [41].

To ensure that our respondents matched the target customers for such luxury goods, we only surveyed consumers with a monthly household income of more than $€ 4,500$. As it is very costly (both in time and money) to collect data among such affluent consumers, and as women are the buyers in four out of every five luxury purchases [42], and probably more in the handbag category, we only surveyed females to control for any confounding effect of gender. Although this focus potentially reduced external validity, it was in line with previous research in the literature on luxury goods $[8,43,44]$. Of note, informed consent was obtained from all individual participants involved in our two experiments. All analyses were conducted using SPSS IBM Statistics 23.

\subsection{Study 1}

Study 1, which consisted of a between-subjects experiment, involved a fictitious luxury brand making handbags (Clodine). It manipulated fashionization (high vs. low fashion) using a unique real luxury bag that actually exists on the market in two different appearances, either with blue flowers (high fashion) or uniformly black (low fashion). Beyond this difference, the two bags did not differ in terms of their form, size, material, or brand prominence. To ensure that the two bags were perceived as luxury goods despite their fictitious brand, their sale price was shown as $€ 2920$. Of note, luxury brands do not price fashion and more classical products lines differently, all things considered (e.g., form, size, material). Figure 2 displays the two experimental treatments.

A pre-test conducted among 68 female consumers (mean age of 41) confirmed that the more frequent ideas that came to mind when exposed to the high-fashion stimulus were "flowers" and "original" vs. "classic" and "elegant" when exposed to the low-fashion stimulus. It also confirmed that the two experimental treatments did not differ in terms of perceived luxury as measured using the items "elitist" and "very expensive": $\mathrm{M}_{\text {high-fashion }}=3.58$ vs. $\mathrm{M}_{\text {low-fashion }}=4.12$ out of 5, $p>0.05$. The two experimental treatments also did not differ in terms of consumption conspicuousness as measured using three ad hoc items (i.e., "Clodine's products signal status/are a sign of distinction/symbolize their owner's success"): $\mathrm{M}_{\text {high-fashion }}=2.84$ vs. $\mathrm{M}_{\text {low-fashion }}=3.12$ out of $\left.5, p>0.05\right)$. Finally, they did not differ in terms of brand conspicuousness as measured using [45] $\left(\mathrm{M}_{\text {high-fashion }}=1.76 \mathrm{vs}\right.$. $\mathrm{M}_{\text {low-fashion }}$ $=1.90$ out of $5, p>0.05$ ). However, and as expected, the two experimental treatments significantly differed in terms of perceived fashionization, as measured using the items "avant-gardist" and "classic" $\left(\mathrm{M}_{\text {high-fashion }}=3.52\right.$ vs. $\mathrm{M}_{\text {low-fashion }}=1.59$ out of $\left.5, p<0.05\right)$. 


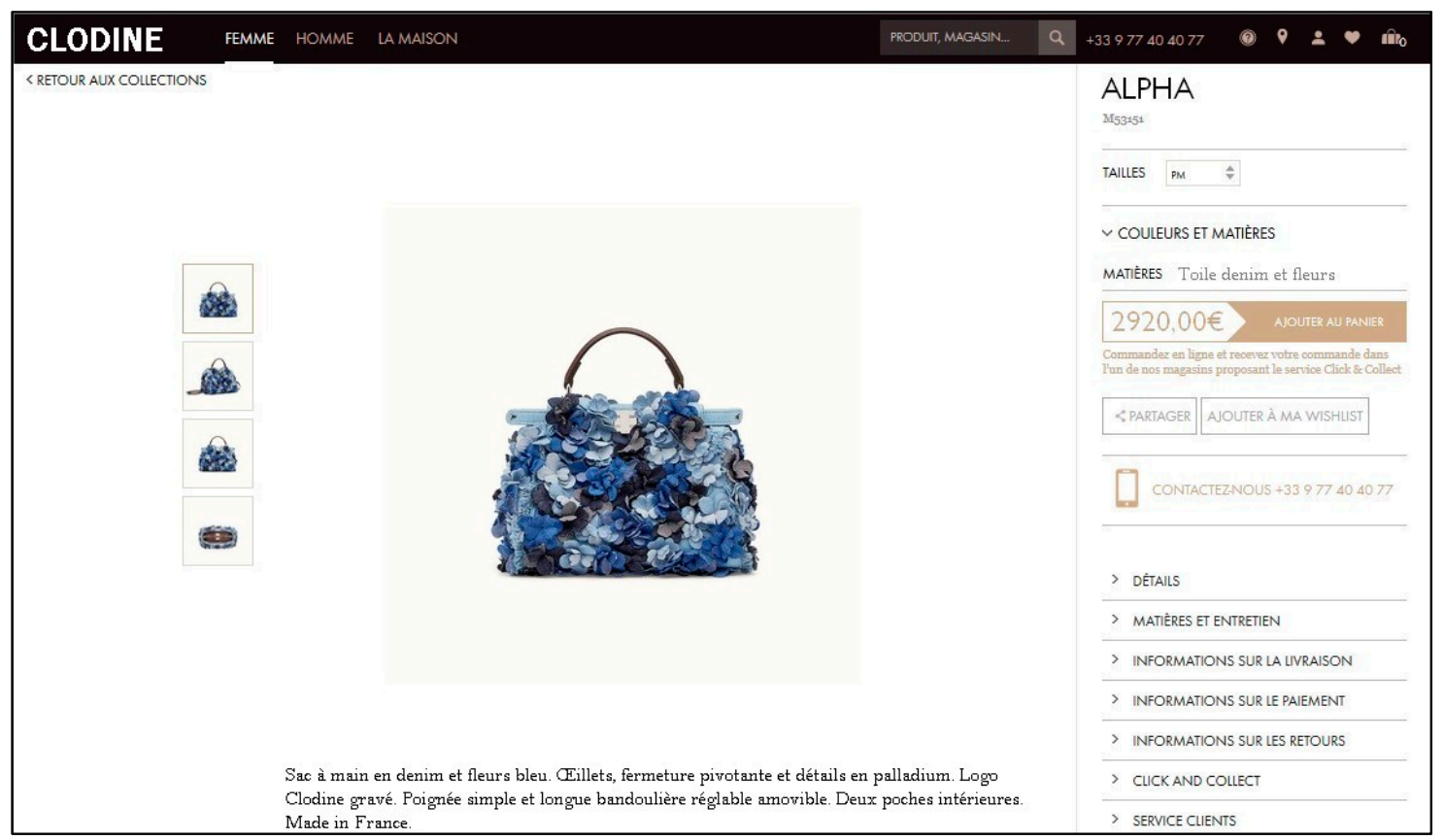

(a) High fashion

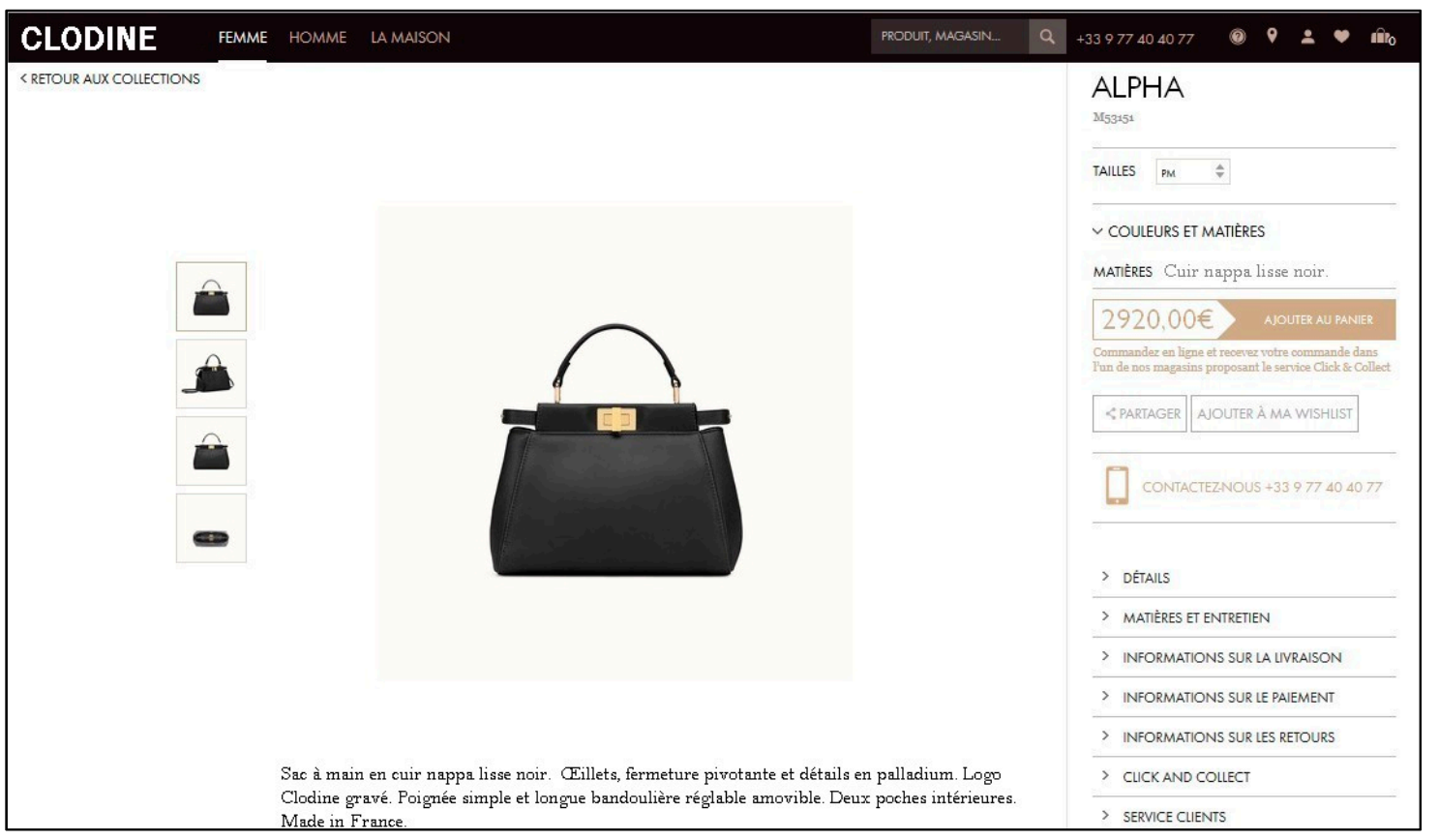

(b) Low fashion

Figure 2. Study 1's experimental treatments: (a) high fashion and (b) low fashion.

Next, 92 French women (mean age of 46) were recruited from the online panel of a professional market research institute (Creatests, Lille, France). They were randomly assigned to the two experimental treatments (high vs. low fashion). Respondents were asked to look at the screenshot of the fictitious luxury bag manufacturer Clodine's website, presenting one of its bags.

To investigate the influence of fashionization on the brand's CSR image, we invited respondents to answer items borrowed from [8]. Specifically, respondents were asked to answer questions regarding the brand's perceived ephemerality (e.g., "This brand's products can be worn for years"), perceived scarcity (i.e., "This brand's products are unique and original"), and CSR image (e.g., "This brand's products seem to follow ethical principles"). Although the focus of this research was on the compatibility 
between luxury and CSR as measured by CSR image, we also measured purchase intention, using a single item [46], to check whether the dual-route model captures effects beyond CSR image. Of note, a strong CSR image has been robustly found to influence purchase intention [47-49].

Respondents' age, monthly household income, involvement in luxury consumption, environmental consciousness, skepticism toward marketing, and familiarity with the Clodine brand were also measured. Respondents were asked to report their monthly household income on a four-item scale (i.e., $€ 4500-€ 6000, € 6000-€ 7500, € 7500-€ 9000$, over $€ 9000$ ). Of the sample, $49 \%$ declared a monthly income of less than $€ 7500$, and $51 \%$ declared more. Involvement in luxury consumption was measured using three items [50]. Environmental consciousness was measured using three items [51]. Skepticism toward marketing was measured using three items [52]. All items were assessed using Likert scales ranging from 1 (= totally agree) to 7 (= totally disagree), as displayed in Table 1.

Table 1. Study 1's concept measurement, composite reliability, and convergent validity.

\begin{tabular}{|c|c|c|c|c|c|c|c|}
\hline \multirow[b]{2}{*}{ Latent Variable } & \multirow[b]{2}{*}{ Items } & \multicolumn{3}{|c|}{$\begin{array}{c}\text { Study } 1 \\
\text { (Fictitious Brand) }\end{array}$} & \multicolumn{3}{|c|}{$\begin{array}{c}\text { Study } 2 \\
\text { (Real Brand) }\end{array}$} \\
\hline & & $\begin{array}{l}\text { Cronbach's } \\
\text { Alpha }\end{array}$ & $\begin{array}{l}\text { D.G. rho } \\
\text { (PCA) }\end{array}$ & AVE & $\begin{array}{l}\text { Cronbach's } \\
\text { Alpha }\end{array}$ & $\begin{array}{l}\text { D.G. rho } \\
\text { (PCA) }\end{array}$ & AVE \\
\hline $\begin{array}{c}\text { Perceived } \\
\text { ephemerality }\end{array}$ & $\begin{array}{l}\text { This brand's products } \\
-\quad \begin{array}{l}\text { can be worn for years } \\
\text { - }\end{array} \\
\text { are timeless and pass the times } \\
\text { can be worn under } \\
\text { any circumstances } \\
\text { - } \quad \begin{array}{l}\text { are going out of } \\
\text { fashion quickly }\end{array}\end{array}$ & 0.850 & 0.899 & 0.691 & 0.826 & 0.885 & 0.658 \\
\hline $\begin{array}{l}\text { Perceived } \\
\text { scarcity }\end{array}$ & $\begin{array}{l}\text { This brand's products are unique } \\
\text { and original }\end{array}$ & $\mathrm{n} / \mathrm{a}$ & $\mathrm{n} / \mathrm{a}$ & $\mathrm{n} / \mathrm{a}$ & $\mathrm{n} / \mathrm{a}$ & $\mathrm{n} / \mathrm{a}$ & $\mathrm{n} / \mathrm{a}$ \\
\hline CSR image & $\begin{array}{l}\text { This brand's products seem to } \\
-\quad \text { follow ethical principles } \\
-\quad \\
\text { - } \quad \text { respect moral principles } \\
\text { respect the environment }\end{array}$ & 0.862 & 0.916 & 0.784 & 0.935 & 0.958 & 0.885 \\
\hline $\begin{array}{l}\text { Purchase } \\
\text { intention }\end{array}$ & $\begin{array}{l}\text { If I had the money, I would buy } \\
\text { products of this brand }\end{array}$ & $\mathrm{n} / \mathrm{a}$ & $\mathrm{n} / \mathrm{a}$ & $\mathrm{n} / \mathrm{a}$ & $\mathrm{n} / \mathrm{a}$ & $\mathrm{n} / \mathrm{a}$ & $\mathrm{n} / \mathrm{a}$ \\
\hline $\begin{array}{l}\text { Environmental } \\
\text { consciousness }\end{array}$ & $\begin{array}{l}\text { I do my best not to buy from } \\
\text { companies that pollute } \\
\text { I always choose the products that } \\
\text { have the least negative effect on the } \\
\text { environment } \\
\text { When I have the choice between two } \\
\text { equivalent products, I always choose } \\
\text { the least polluting }\end{array}$ & 0.838 & 0.903 & 0.753 & 0.851 & 0.910 & 0.770 \\
\hline $\begin{array}{l}\text { Involvement in } \\
\text { luxury } \\
\text { consumption }\end{array}$ & $\begin{array}{l}\text { I could talk about luxury for hours } \\
\text { I'm not interested in luxury } \\
\text { I almost never buy luxury products }\end{array}$ & 0.703 & 0.835 & 0.615 & 0.748 & 0.856 & 0.641 \\
\hline $\begin{array}{l}\text { Skepticism } \\
\text { toward } \\
\text { marketing }\end{array}$ & $\begin{array}{l}\text { I trust companies } \\
\text { Brands do not lie } \\
\text { Advertising is a reliable source of } \\
\text { information }\end{array}$ & 0.794 & 0.879 & 0.708 & 0.805 & 0.885 & 0.717 \\
\hline $\begin{array}{l}\text { LV customer } \\
(\text { Yes/No) }\end{array}$ & $\begin{array}{l}\text { In the last two years, have you } \\
\text { purchased a Louis Vuitton product, } \\
\text { or received one as a gift? }\end{array}$ & & & & $\mathrm{n} / \mathrm{a}$ & $\mathrm{n} / \mathrm{a}$ & $\mathrm{n} / \mathrm{a}$ \\
\hline
\end{tabular}

AVE, average variance extracted; $\mathrm{n} / \mathrm{a}$, not applicable.

No significant differences were observed between the participants randomly assigned to either condition in terms of age $\left(\mathrm{F}_{(1,90)}=0.001, p>0.05\right)$, monthly household income $\left(\chi^{2}{ }_{(3)}=1.647\right.$, $p>0.05)$, involvement in luxury consumption $\left(\mathrm{F}_{(1,90)}=2.557, p>0.05\right)$, environmental consciousness $\left(\mathrm{F}_{(1,90)}=1.056, p>0.05\right)$, skepticism toward marketing $\left(\mathrm{F}_{(1,90)}=3.619, p>0.05\right)$, and familiarity with the Clodine brand $\left(\mathrm{F}_{(1,90)}=1.075, p>0.05\right)$. 


\subsection{Study 2}

Aimed at replicating Study 1 with a more real luxury setting, Study 2 consisted of a second between-subjects experiment involving a real full page of products from the Louis Vuitton website. It manipulated fashionization (high vs. low fashion) using pairs of real luxury bags that only differed in terms of their appearance, either decorated (high fashion) or uniform (low fashion). Beyond this difference, the pairs of bags did not differ in terms of their form, size, material, or brand prominence. Products were priced between $€ 2150$ and $€ 4000$ but were strictly controlled over the two stimuli. Figure 3 displays the two experimental treatments.
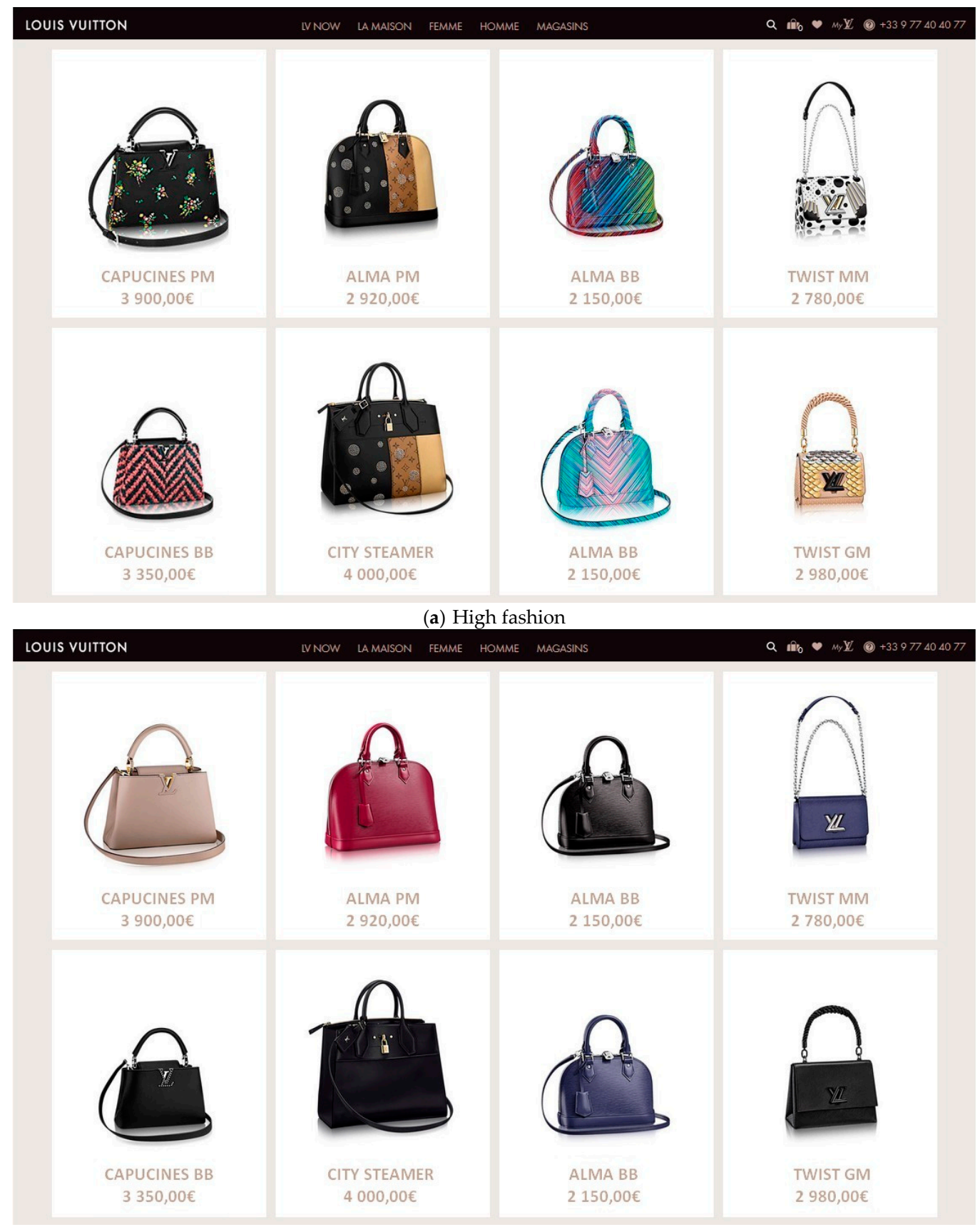

(b) Low fashion

Figure 3. Study 2's experimental stimuli: (a) high fashion and (b) low fashion. 
A pre-test similar to the one conducted for Study 1 involved 98 female consumers (mean age of 41). It confirmed that the more frequent ideas that came to mind when exposed to the high-fashion stimulus were "colorful" and "original" vs. "classic" and "elegant" when exposed to the low-fashion stimulus. It also confirmed that the two experimental treatments did not differ in terms of perceived luxury $\left(\mathrm{M}_{\text {high-fashion }}=3.83\right.$ vs. $\mathrm{M}_{\text {low-fashion }}=4.18$ out of $\left.5, p>0.05\right)$, consumption conspicuousness $\left(\mathrm{M}_{\text {high-fashion }}\right.$ $=2.89$ vs. $\mathrm{M}_{\text {low-fashion }}=3.10$ out of $\left.5, p>0.05\right)$, and brand conspicuousness $\left(\mathrm{M}_{\text {high-fashion }}=3.25 \mathrm{vs}\right.$. $\mathrm{M}_{\text {low-fashion }}=3.05$ out of $5, p>0.05$ ). However, and as expected, the two experimental treatments significantly differed in terms of perceived fashionization: $\mathrm{M}_{\text {high-fashion }}=3.04 \mathrm{vs}$. $\mathrm{M}_{\text {low-fashion }}=1.64$ out of $5, p<0.05$.

Next, 94 French women (mean age of 47) were recruited from the online panel of the same professional market research institute as for Study 1 . They were randomly assigned between the two experimental treatments (high vs. low fashion). They answered the same questions as the respondents in Study 1, plus a specific question about their consumption of Louis Vuitton products. Of the sample, $45 \%$ declared a monthly household income ranging between $€ 4500$ and $€ 7500$, and $55 \%$ declared more.

No significant differences were observed between the participants randomly assigned to either condition in terms of age $\left(\mathrm{F}_{(1,92)}=0.623, p>0.05\right)$, monthly household income $\left(\chi^{2}{ }_{(3)}=0.932\right.$, $p>0.05)$, involvement in luxury consumption $\left(\mathrm{F}_{(1,92)}=0.051, p>0.05\right)$, environmental consciousness $\left(\mathrm{F}_{(1,92)}=0.009, p>0.05\right)$, skepticism toward marketing $\left(\mathrm{F}_{(1,92)}=0.002, p<0.05\right)$, familiarity with the Louis Vuitton brand $\left(\mathrm{F}_{(1,92)}=0.003, p>0.05\right)$, and consumption of Louis Vuitton products $\left(\chi^{2}{ }_{(1)}=0.406\right.$, $p>0.05$ ). Of note, $54 \%$ of the respondents declared that they had purchased a Louis Vuitton product, or received one as a gift, within the last two years.

\subsection{Preliminary Analyses}

All scales proved to be reliable and valid, as shown by Table 1 (results of the confirmatory analysis using the partial least squares structural equation modeling approach on XLSTAT2019).

Of note, the initial three-item scale used to measure perceived scarcity displayed a poor reliability index, which may be explained by the experimental design used in this study. First, our manipulation used an online website offering products that were immediately and easily available, which disqualifies the limited-supply item of the scale. Second, we controlled for the products' materials, which limits the relevance of its "rare and precious materials" item. Consequently, scarcity was ultimately measured by a single item focusing on the uniqueness and originality of the brand.

Table 2 reports the descriptive statistics for the variables used in Studies 1 and 2.

Table 2. Descriptive statistics.

\begin{tabular}{|c|c|c|c|c|c|c|c|c|c|}
\hline & \multirow{2}{*}{ Fashionization } & \multicolumn{2}{|c|}{ Ephemerality } & \multicolumn{2}{|c|}{ Scarcity } & \multicolumn{2}{|c|}{ CSR Image } & \multicolumn{2}{|c|}{ Purchase Intention } \\
\hline & & Mean & SD & Mean & SD & Mean & SD & Mean & SD \\
\hline \multirow{2}{*}{$\begin{array}{c}\text { Study } 1 \\
\text { (fictitious } \\
\text { brand) }\end{array}$} & $\begin{array}{c}\text { Low } \\
(N=47)\end{array}$ & 2.91 & 1.06 & 4.06 & 1.48 & 4.47 & 0.92 & 4.09 & 1.72 \\
\hline & $\begin{array}{c}\text { High } \\
(N=45)\end{array}$ & 4.29 & 1.49 & 5.27 & 1.42 & 4.38 & 0.99 & 3.89 & 1.82 \\
\hline \multirow{2}{*}{$\begin{array}{c}\text { Study } 2 \\
\text { (real brand) }\end{array}$} & $\begin{array}{c}\text { Low } \\
(N=49)\end{array}$ & 1.96 & 1.24 & 5.43 & 1.59 & 4.61 & 1.48 & 5.69 & 1.83 \\
\hline & $\begin{array}{c}\text { High } \\
(N=45)\end{array}$ & 2.45 & 1.44 & 6.07 & 1.29 & 4.70 & 1.33 & 5.51 & 1.73 \\
\hline
\end{tabular}

\section{Results}

We tested the hypotheses using a bootstrapping regression for indirect effects $[53,54]$, with 5000 resamples. Fashionization was introduced as a dummy variable ( $0=$ low fashion, $1=$ high fashion). We first ran Model 4 [54] script to test the effect of the ephemerality and scarcity routes on CSR image, then Model 6 in order to include the effects on purchase intention. The analyses controlled for 
respondents' age, monthly household income, involvement in luxury consumption, environmental consciousness, skepticism toward marketing, and consumption of Louis Vuitton products (for Study 2 only).

\subsection{Test of the Conceptual Model for a Fictitious Brand (Study 1)}

The first two columns of Table 3 display the results of Study 1.

Table 3. Test of the conceptual dual-route model.

\begin{tabular}{|c|c|c|c|c|}
\hline \multirow[b]{2}{*}{ Paths } & \multicolumn{2}{|c|}{$\begin{array}{c}\text { Study } 1 \\
\text { Fictitious Brand) }\end{array}$} & \multicolumn{2}{|c|}{$\begin{array}{c}\text { Study } 2 \\
\text { (Real Brand) }\end{array}$} \\
\hline & $\beta$ & $t$ & $\beta$ & $t$ \\
\hline \multicolumn{5}{|l|}{ Dependent variable: Perceived ephemerality } \\
\hline Fashionization $\rightarrow$ Perceived ephemerality & 1.29 & $4.77^{* * *}$ & 0.48 & $1.97 *$ \\
\hline Environmental consciousness $\rightarrow$ Perceived ephemerality & -0.16 & -1.69 & 0.02 & 0.27 \\
\hline Involvement in luxury consumption $\rightarrow$ Perceived ephemerality & -0.14 & -1.37 & -0.06 & -0.60 \\
\hline Skepticism toward marketing $\rightarrow$ Perceived ephemerality & 0.13 & 1.10 & 0.20 & $2.15 *$ \\
\hline LV customer $(\mathrm{Y} / \mathrm{N}) \rightarrow$ Perceived ephemerality & & & -0.23 & -0.87 \\
\hline Monthly household income $\rightarrow$ Perceived ephemerality & -0.13 & -0.90 & -0.06 & -0.36 \\
\hline Age $\rightarrow$ Perceived ephemerality & 0.00 & 0.01 & -0.03 & $-2.60 * *$ \\
\hline \multicolumn{5}{|l|}{ Dependent variable: Perceived scarcity } \\
\hline Fashionization $\rightarrow$ Perceived scarcity & 1.40 & $4.76^{* * *}$ & 0.58 & $2.10 *$ \\
\hline Environmental consciousness $\rightarrow$ Perceived scarcity & 0.09 & 0.85 & -0.07 & -0.80 \\
\hline Involvement in luxury consumption $\rightarrow$ Perceived scarcity & 0.14 & 1.29 & 0.20 & 1.78 \\
\hline Skepticism toward marketing $\rightarrow$ Perceived scarcity & -0.30 & $-2.29 *$ & -0.18 & -0.170 \\
\hline LV customer $(\mathrm{Y} / \mathrm{N}) \rightarrow$ Perceived scarcity & & & 0.27 & 0.93 \\
\hline Monthly household income $\rightarrow$ Perceived scarcity & 0.16 & 1.04 & 0.04 & 0.23 \\
\hline Age $\rightarrow$ Perceived scarcity & 0.01 & 0.64 & 0.01 & 0.86 \\
\hline \multicolumn{5}{|l|}{ Dependent variable: CSR image } \\
\hline Fashionization $\rightarrow$ CSR image & 0.08 & 0.36 & -0.15 & -0.69 \\
\hline Perceived ephemerality $\rightarrow$ CSR image & -0.18 & $-2.60 *$ & 0.01 & 0.10 \\
\hline Perceived scarcity $\rightarrow$ CSR image & 0.16 & $2.54 *$ & 0.26 & $3.09 * * *$ \\
\hline Environmental consciousness $\rightarrow$ CSR image & 0.05 & 0.76 & 0.11 & 1.52 \\
\hline Involvement in luxury consumption $\rightarrow$ CSR image & 0.08 & 1.20 & 0.10 & 1.14 \\
\hline Skepticism toward marketing $\rightarrow$ CSR image & -0.18 & $-2.36 *$ & -0.47 & $-5.96^{* * *}$ \\
\hline LV customer $(\mathrm{Y} / \mathrm{N}) \rightarrow \mathrm{CSR}$ image & & & 0.12 & 0.57 \\
\hline Monthly household income $\rightarrow$ CSR image & 0.04 & 0.45 & 0.17 & 1.39 \\
\hline Age $\rightarrow$ CSR image & -0.00 & -0.07 & 0.01 & 1.39 \\
\hline Mediation effects & Effect & CI & Effect & CI \\
\hline Fashionization $\rightarrow$ Perceived ephemerality $\rightarrow$ CSR image & -0.23 & {$[-0.52 ;-0.06]$} & 0.00 & {$[-0.09 ; 0.13]$} \\
\hline Fashionization $\rightarrow$ Perceived scarcity $\rightarrow$ CSR image & 0.21 & {$[0.07 ; 0.46]$} & 0.15 & {$[0.01 ; 0.48]$} \\
\hline
\end{tabular}

The results, as shown in the first two columns of Table 3 (Model 4), show that fashionization has a significant effect on perceived ephemerality $(\beta=1.29, p<0.05)$ and scarcity $(\beta=1.40$, $p<0.05)$. More precisely, fashionization triggers higher perceived ephemerality $\left(\mathrm{M}_{\text {low-fashion }}=2.91\right.$ vs. $\left.\mathrm{M}_{\text {high-fashion }}=4.29\right)$ and scarcity $\left(\mathrm{M}_{\mathrm{low} \text {-fashion }}=4.06 \mathrm{vs}\right.$. $\left.\mathrm{M}_{\text {high-fashion }}=5.27\right)$. In turn, perceived ephemerality harms CSR image $(\beta=-0.18, p<0.05)$, whereas perceived scarcity enhances it $(\beta=0.16$, $p<0.05)$. Finally, as the confidence interval (CI) shown in Table 3 excludes 0 , we conclude that perceived ephemerality and scarcity mediate the relationship between fashionization and CSR image. Using Model 6 [54], we also found that the dual mediating effect extends to purchase intention. On the one hand, fashionization triggers higher perceived ephemerality, which first impairs CSR image, then reduces purchase intention (total effect $=-0.16$, IC $=[-0.41 ;-0.05]$ ). On the other hand, fashionization triggers higher perceived scarcity, which first enhances CSR image, then increases purchase intention (total effect $=0.16, \mathrm{IC}=[0.05 ; 0.40])$. 
Altogether, these results provide empirical support for the ephemerality-scarcity dual-route model (H1 and H2) and expand previous work on luxury-CSR compatibility, which is discussed in depth in the Theoretical Contributions section.

\subsection{Test of the Conceptual Model for a Real Brand (Study 2)}

We replicated the analyses run in Study 1 for the Louis Vuitton brand. As shown in the last two columns of Table 3 (Model 4), fashionization has a significant effect on perceived ephemerality ( $\beta=0.57, p<0.05)$ and scarcity $(\beta=0.48, p<0.05)$. More precisely, fashionization triggers higher perceived ephemerality $\left(\mathrm{M}_{\text {low-fashion }}=1.96 \mathrm{vs}\right.$. $\left.\mathrm{M}_{\text {high-fashion }}=2.45\right)$ and scarcity $\left(\mathrm{M}_{\text {low-fashion }}=5.43 \mathrm{vs}\right.$. $\left.\mathrm{M}_{\text {high-fashion }}=6.07\right)$. However, contrary to Study 1 , only perceived scarcity $(\beta=0.25, p<0.01)$ has a mediating effect on CSR image, as the confidence interval shown in Table 3 excludes 0 . The application of Model 6 [54] shows that, contrary to Study 1, the mediating effect of perceived scarcity does not extend to purchase intention (total effect $=0.01, \mathrm{IC}=[-0.03 ; 0.14]$ ), suggesting that in a real-life setting, CSR image has little influence on purchase intention.

\section{Discussion}

This research explored whether fashionization impedes luxury brands' CSR image. Findings from two experiments showed that, in the case of a fictitious luxury brand, perceived ephemerality and scarcity mediate the effect of fashionization on brand CSR image with opposite effects that extend to purchase intention. In the case of a real luxury brand, however, only the scarcity route appears significant and CSR image no longer transfers to purchase intention. As a result, fashionization does not impede luxury brands' CSR image.

These research findings are particularly relevant because the experiments involved affluent respondents (i.e., all respondents had a monthly household income of over $€ 4500$, of whom half declared over $€ 7500$ ). Additionally, half of them were actual consumers of the Louis Vuitton brand, confirming that our respondents actually matched the target customers for such luxury goods. They thus provided valuable theoretical contributions and practical managerial implications for luxury brands' CSR communication.

\subsection{Theoretical Contributions}

This research makes a general contribution to the nascent body of literature on perceptions of compatibility between luxury and CSR $[8,11,17,18,22,23]$ by examining a new and very timely driver, namely fashionization. Its finding that fashionization does not impede CSR image also provides a number of specific contributions.

First, this research corroborates pioneering work on the compatibility between luxury and CSR [8] by replicating their major finding on the influence of ephemerality and scarcity. Considering a fictitious luxury brand's CSR image, as they also did, we showed that ephemerality erodes the brand's CSR image while scarcity enhances it, which answers the call to further explore the influence of scarcity cues on subsequent decision-making [35]. Going further, this research shows that ephemerality and scarcity are still significant ways to build CSR image when considered as perceptual psychological mechanisms instead of given objective data, respectively, depending on the product category or the price of the product. As such, we contend that perceived ephemerality and scarcity are two alternative routes to explaining brand CSR image and propose the ephemerality-scarcity dual-route model as a relevant theoretical framework to further explore the compatibility between luxury and CSR.

Second, this research also enriches pioneering work [8] by testing the ephemerality-scarcity dual-route model on both fictitious and real luxury brands. For both types of brands, fashionization increases perceptions of ephemerality. However, perceived ephemerality only damages CSR image when the brand is fictitious. In the case of a real luxury brand, namely Louis Vuitton in Study 2, only the scarcity route appears relevant to build CSR image. As such, our research questions the use of fictitious brands when studying the effects of CSR initiatives and communication. In an experimental 
setting, using a fictitious (hence unfamiliar) brand allows controlling for the effects of respondents' pre-existing brand knowledge, especially regarding CSR, as they have not been previously exposed to any CSR communications or good or bad "buzz". However, using fictitious instead of real brands can undermine the reliability of experimental findings. For fictitious brands, as consumers must form their attitude from scratch, any little piece of new information is more extensively processed and has more influence on the resulting attitude. In contrast, due to prior direct or indirect experience [55], consumers hold pre-existing beliefs and attitudes that are more stable, certain, and consistent [56,57], hence more resistant to persuasion for familiar brands than unfamiliar brands [58,59]. This limits the influence of any new information in the cognitive structure related to familiar brands, which should be particularly true when focusing on luxury brands, which are usually expected to excel in every domain, including CSR initiatives. From an academic point of view, underlining the role of brand manipulation as a boundary condition for relevance in the mechanisms that build brands' image alerts researchers in the field of luxury goods to the need for systematic replication, with real luxury brands, of relevant experimental findings based on fictitious luxury brands.

Third, our finding that fashionization enhances perceived scarcity is also insightful. The generally accepted idea that fashion can be in opposition to modesty and discreetness does not mean that a greater focus on fashion entails a massive production, distribution, and consumption in the luxury domain. On the contrary, like more classical brands, brands that embrace fashionization entail high prices, rare raw materials, excellent craftsmanship, and exceptional savoir-faire. Furthermore, they also set the season's fashion trends through their idolized designers and the introduction of limited but more original and iconic designs and styles that address the niche of avant-gardist consumers. As such, the observation that "luxury implies scarcity" [36] (p. 316) may appear even truer for fashion luxury brands. This finding can be interpreted through the lens of the "virtual scarcity" concept [39], by considering fashionization as a specific information-based rarity tactic that creates the illusion of scarcity [37] in addition to other price-, distribution-, and advertising-related tactics. Put differently, beyond scarcity appeals that are driven by "excess demand" or "limited supply" [60], we show that scarcity appeals can also be based on "original supply".

Moreover, our finding that fashionization does not impede CSR image runs counter to common wisdom, which tends to assume the opposite, that is, that fashion luxury brands would be less legitimate for communication on CSR. Since our experiments show that the ephemerality route's effect is non-significant in the case of a real brand, the increasing adoption of fast-fashion codes [1,42] does not threaten luxury brands' CSR efforts. This important result is in line with previous research suggesting that luxury brands can become leaders in sustainability as long as they embody artisanal quality [2]. Going further, our finding that fashion luxury brands enhance CSR image while conspicuous ones have less favorable CSR perceptions $[10,18]$ calls for further research on the theoretical distinction between fashion and conspicuousness in the luxury domain.

\subsection{Managerial Implications}

Luxury brands have recently taken effective steps to create and reinforce their CSR programs. Their future would depend on their ability to address important social and environmental issues [2]. In its latest report on fashion sustainability, the Boston Consulting Group notes that premium luxury brands scored far higher than mass fashion brands on sustainability performance [61]. The findings from the research presented in this article show that these sustainability efforts by luxury brands are worth the investment, even for brands that have embraced fashionization.

More specifically, contrary to common wisdom, the results provide reassurance for managers of famous, well-established fashion brands that embracing fashionization does not contradict their investment in CSR programs because it enhances the brand's perceived scarcity and translates into positive CSR brand image. Consequently, while it has been stated that "manufacturers or sellers of scarce, ephemeral luxury products will find it difficult to position their offerings as responsible" [8] (p. 51), we conclude that luxury houses selling ephemeral products such as leather accessories can 
use fashionization to develop an illusion of scarcity and suggest that their brands are sustainable. This echoes an interesting recommendation [18] according to which luxury brands should convince the public about their CSR by disassociating luxury from the idea of wasting natural resources and rather suggesting the scarcity that characterizes their products, without explicitly insisting on it to avoid potential critics. Several tactics can subtly nourish perceptions of scarcity, such as the rarity of the materials used, limited-edition capsule collections, and even the elevation of the luxury brand design to the status of an art (e.g., exhibitions about the brand in prestigious museums and cities, "starification" of the brand's designers). Like their ever-growing more famous competitors, less well-known luxury fashion brands should also capitalize on perceptions of scarcity but avoid triggering perceptions of ephemerality.

Regarding the absence of any significant relationship between brand CSR image and purchase intention in the case of real brands, it can result from ceiling effects, that is, our respondents already had a high purchase intention for the Louis Vuitton brand, making the net effect of brand CSR image non-significant. Consumers who buy luxury goods are more attentive to attributes such as quality and prestige than sustainability [24]. Still, this should not discourage managers from investing in CSR programs as the effect of CSR performance on purchase intention is asymmetric [62], where a poor CSR performance damages attitudes and purchase intention far more than a good performance enhances them. Consequently, luxury brands have no option but to continue their CSR initiatives. Not only does investment in CSR provide some protection from potential negative effects when irresponsible behavior is suspected, it also allows brands to meet consumer expectations, avoid activist attacks and "bad buzz", and stand up to competition from new and smaller brands that are positioning themselves as ethical and socially responsible.

\subsection{Limitations and Further Research}

Although this research has important theoretical and practical implications, some limitations must be acknowledged that suggest avenues for future research. First, scarcity was measured by a single item consisting of the brand's uniqueness and originality, but scarcity involves other attributes, including natural scarcity and techno-scarcity [37]. More research is needed to test our conceptual framework with different types of scarcity. Second, the experiments were conducted on a sample of women only, who were exposed to brands in a specific product category, namely handbags. Although this procedure increased the experiments' internal validity, further studies should replicate the presented framework on other product categories that are purchased by both men and women. Follow-up research could also consider replicating our findings using other luxury brands than the Louis Vuitton brand. As luxury brands arguably vary in terms of their adoption of fashionization and in terms of brand familiarity, it would be useful to try to replicate our findings under new boundary conditions. Furthermore, this research, with its conceptual grounding drawn from previous literature questioning the compatibility between luxury and CSR, focused mainly on fashionization to keep up with the latest managerial changes in the luxury industry [38]. To do so, it considered real products and manipulated their appearance, either uniform or stylish, but controlled for the handbag model (form, size, and material) and brand prominence. Future research could explore the influence of other potential manipulations of fashionization on CSR image, including the products' objective attributes (e.g., form, size, material) or more artificial manipulations such as advertising using fashion codes (e.g., fashionista models, street settings) or the association with a fashion designer, a fashion influencer on social media, or a trendy celebrity. Going further, future research should more systematically evaluate the impact of the strategies used by luxury brands on a daily basis on their CSR image, as CSR has to be more than skin deep to meet new luxury consumers' expectations.

Author Contributions: The three authors contributed equally to this research. Writing-original draft, B.P., T.D. and A.M.C. All authors have read and agreed to the published version of the manuscript.

Funding: This research received no external funding. 
Conflicts of Interest: The authors declare no conflict of interest.

Compliance with Ethical Standards: All procedures performed in this article's studies were in accordance with the 1964 Declaration of Helsinki and its later amendments or comparable ethical standards. Informed consent was obtained from all individual participants included in the studies.

\section{References}

1. Kapferer, J.-N. Le Paradoxe Du Luxe: Une Croissance Qui Fait Problème. 2016. Available online: https: //www.youtube.com/watch?v=VFFkesm8tXg (accessed on 5 January 2020).

2. Joy, A.; Sherry, J.F., Jr.; Venkatesh, A.; Wang, J.; Chan, R. Fast fashion, sustainability, and the ethical appeal of luxury brands. Fash. Theory 2012, 16, 273-295. [CrossRef]

3. Fletcher, K. Sustainable Fashion and Textiles: Design Journeys; Routledge: London, UK, 2013.

4. Jackson, T.; Shaw, D. Mastering Fashion Marketing; Palgrave Macmillan: Basingstoke, UK, 2008.

5. Morgan, L.R.; Birtwistle, G. An investigation of young fashion consumers' disposal habits. Int. J. Consum. Stud. 2009, 33, 190-198. [CrossRef]

6. Caniato, F.; Caridi, M.; Crippa, L.; Moretto, A. Environmental sustainability in fashion supply chains: An exploratory case-based research. Int. J. Prod. Econ. 2012, 135, 659-670. [CrossRef]

7. Kapferer, J.-N.; Valette-Florence, P. Beyond rarity: The paths of luxury desire. How luxury brands grow yet remain desirable. J. Prod. Brand Manag. 2016, 25, 120-133. [CrossRef]

8. Janssen, C.; Vanhamme, J.; Lindgreen, A.; Lefebvre, C. The Catch-22 of Responsible Luxury: Effects of Luxury Product Characteristics on Consumers' Perception of Fit with Corporate Social Responsibility. J. Bus. Ethics 2014, 119, 45-57. [CrossRef]

9. Daveu, M.C. What's next? Emotional, experiential, innovative and sustainable: A vision for the future. In Proceedings of the The Monaco Symposium on Luxury, Moneghetti, Monaco, 12-13 April 2018.

10. Winston, A. Luxury Brands Can No Longer Ignore Sustainability. 2016. Available online: https://hbr.org/ 2016/02/luxury-brands-can-no-longer-ignore-sustainability (accessed on 5 January 2020).

11. Carrigan, M.; Moraes, C.; McEachern, M. From conspicuous to considered fashion: A harm-chain approach to the responsibilities of luxury-fashion businesses. J. Mark. Manag. 2013, 29, 1277-1307. [CrossRef]

12. Kapferer, J.-N.; Michaut, A. Luxury and sustainability: A common future? The match depends on how consumers define luxury. Lux. Res. J. 2015, 1, 3-17. [CrossRef]

13. Achabou, M.A.; Dekhili, S. Luxury and sustainable development: Is there a match? J. Bus. Res. 2013, 66, 1896-1903. [CrossRef]

14. Torelli, C.J.; Monga, A.B.; Kaikati, A.M. Doing poorly by doing good: Corporate social responsibility and brand concepts. J. Consum. Res. 2012, 38, 948-963. [CrossRef]

15. Bhattacharya, C.B.; Sen, S. Consumer-company identification: A framework for understanding consumers' relationship with companies. J. Mark. 2003, 67, 76-88. [CrossRef]

16. Hennigs, N.; Wiedmann, K.P.; Klarmann, C.; Behrens, S. Sustainability as part of the luxury essence: Delivering value through social and environmental excellence. J. Corp. Citizsh. 2013, 52, 25-35. [CrossRef]

17. Kapferer, J.-N.; Michaut, A. Is luxury compatible with sustainability: Luxury consumers viewpoint. J. Brand Manag. 2014, 21, 1-22. [CrossRef]

18. Dekhili, S.; Achabou, M.A. Luxe et développement durable: Quelles sources de dissonance? Decis. Mark. 2016, 83, 97-121. [CrossRef]

19. Godart, F.; Seong, S. Is sustainable luxury fashion possible. In Sustainable Luxury: Managing Social and Environmental Performance in Iconic Brands; Greenleaf Publishing: Sheffield, UK, 2014.

20. Amatulli, C.; De Angelis, M.; Costabile, M.; Guido, G. Sustainable Luxury Brands: Evidence from Research and Implications for Managers; Palgrave Macmillan: London, UK, 2017.

21. McDaniel, S.W.; Rylander, D.H. Strategic green marketing. J. Consum. Mark. 1993, 10, 4-10. [CrossRef]

22. Janssen, C.; Vanhamme, J.; Leblanc, S. Should luxury brands say it out loud? Brand conspicuousness and consumer perceptions of responsible luxury. J. Bus. Res. 2017, 77, 167-174. [CrossRef]

23. Steinhart, Y.; Ayalon, O.; Puterman, H. The effect of an environmental claim on consumers' perceptions about luxury and utilitarian products. J. Clean. Prod. 2013, 53, 277-286. [CrossRef]

24. Davies, I.A.; Lee, Z.; Ahonkhai, I. Do consumers care about ethical-luxury? J. Bus. Ethics 2012, 106, 37-51. [CrossRef] 
25. Moraes, C.; Carrigan, M.; Bosangit, C.; Ferreira, C.; McGrath, M. Understanding ethical luxury consumption through practice theories: A study of fine jewellery purchases. J. Bus. Ethics 2017, 145, 525-543. [CrossRef]

26. Plewa, C.; Conduit, J.; Quester, P.G.; Johnson, C. The impact of corporate volunteering on CSR image: A consumer perspective. J. Bus. Ethics 2015, 127, 643-659. [CrossRef]

27. Pomering, A.; Johnson, L.W. Advertising corporate social responsibility initiatives to communicate corporate image: Inhibiting scepticism to enhance persuasion. Corp. Commun. Int. J. 2009, 14, 420-439. [CrossRef]

28. Krishnan, H.S. Characteristics of memory associations: A consumer-based brand equity perspective. Int. J. Res. Mark. 1996, 13, 389-405. [CrossRef]

29. Berthon, P.; Pitt, L.; Parent, M.; Berthon, J.P. Aesthetics and ephemerality: Observing and preserving the luxury brand. Calif. Manag. Rev. 2009, 52, 45-66. [CrossRef]

30. Kawamura, Y. Fashion-ology: An Introduction to Fashion Studies; Bloomsbury Publishing: London, UK, 2018.

31. Barnes, L.; Lea-Greenwood, G. Fast fashioning the supply chain: Shaping the research agenda. J. Fash. Mark. Manag. Int. J. 2006, 10, 259-271. [CrossRef]

32. Henninger, C.E.; Alevizou, P.J.; Goworek, H.; Ryding, D. Sustainability in Fashion: A Cradle to Upcycle Approach; Springer International Publishing: Cham, Switzerland, 2017.

33. Clark, H. SLOW + FASHION-An oxymoron-or a promise for the future? Fash. Theory 2008, 12, 427-446. [CrossRef]

34. Joy, A.; Peña, C. Sustainability and the fashion industry: Conceptualizing nature and traceability. In Sustainability in Fashion: A Cradle to Upcycle Approach; Springer International Publishing: Cham, Switzerland, 2017; pp. 31-54.

35. Roux, C.; Goldsmith, K.; Bonezzi, A. On the psychology of scarcity: When reminders of resource scarcity promote selfish (and generous) behavior. J. Consum. Res. 2015, 42, 615-631. [CrossRef]

36. Kapferer, J.-N.; Bastien, V. The Luxury Strategy: Break the Rules of Marketing to Build Luxury Brands; Kogan Page Publishers: London, UK, 2012.

37. Catry, B. The great pretenders: The magic of luxury goods. Bus. Strategy Rev. 2003, 14, 10-17. [CrossRef]

38. Giacalone, J.A. The Market for Luxury Goods: The Case of the Comité Colbert1. South. Bus. Rev. 2006, 32, 33-40.

39. Kapferer, J.-N. The end of luxury as we knew it? In Advances in Luxury Brands Management; Kapferer, J.-N., Kernstock, J., Brexendorf, T.O., Powell, S.M., Eds.; Palgrave Macmillan: Cham, Switzerland, 2017; pp. $25-41$.

40. Kapferer, J.-N. Kapferer on Luxury: How Luxury Brands Can Grow yet Remain Rare; Kogan Page Publishers: London, UK, 2015.

41. Bain Company. Luxury Goods Worldwide Market Study. 2017. Available online: https://www.bain.com/ insights/luxury-goods-worldwide-market-study-fall-winter-2017/ (accessed on 27 December 2019).

42. Okonkwo, U. Luxury Fashion Branding: Trends, Tactics, Techniques; Palgrave Macmillan: Basingstoke, UK, 2007.

43. Lee, J.E.; Watkins, B. YouTube vloggers' influence on consumer luxury brand perceptions and intentions. J. Bus. Res. 2016, 69, 5753-5760. [CrossRef]

44. Perez, M.E.; Castaño, R.; Quintanilla, C. Constructing identity through the consumption of counterfeit luxury goods. Qual. Mark. Res. Int. J. 2010, 13, 219-235. [CrossRef]

45. Han, Y.J.; Nunes, J.C.; Drèze, X. Signaling status with luxury goods: The role of brand prominence. J. Mark. 2010, 74, 15-30. [CrossRef]

46. Bergkvist, L.; Rossiter, J.R. The predictive validity of multiple-item versus single-item measures of the same constructs. J. Mark. Res. 2007, 44, 175-184. [CrossRef]

47. Creyer, E.H.; Ross, W.T. The influence of firm behavior on purchase intention: Do consumers really care about business ethics? J. Consum. Mark. 1997, 14, 421-432. [CrossRef]

48. Ko, E.; Hwang, Y.K.; Kim, E.Y. Green marketing' functions in building corporate image in the retail setting. J. Bus. Res. 2013, 66, 1709-1715. [CrossRef]

49. Mohr, L.A.; Webb, D.J.; Harris, K.E. Do consumers expect companies to be socially responsible? The impact of corporate social responsibility on buying behavior. J. Consum. Aff. 2001, 35, 45-72. [CrossRef]

50. Dubois, B.; Laurent, G. Attitudes toward the concept of luxury: An exploratory analysis. In Asia Pacific Advances in Consumer Research; Leong, S.M., Cote, J.A., Eds.; Association for Consumer Research: Singapore, 1994; Volume 1, pp. 273-278.

51. Parguel, B.; Benoît-Moreau, F.; Russell, C.A. Can evoking nature in advertising mislead consumers? The power of 'executional greenwashing'. Int. J. Advert. 2015, 34, 107-134. [CrossRef] 
52. Obermiller, C.; Spangenberg, E.R. Development of a scale to measure consumer skepticism toward advertising. J. Consum. Psychol. 1998, 7, 159-186. [CrossRef]

53. Preacher, K.J.; Rucker, D.D.; Hayes, A.F. Addressing moderated mediation hypotheses: Theory, methods, and prescriptions. Multivar. Behav. Res. 2007, 42, 185-227. [CrossRef]

54. Preacher, K.J.; Hayes, A.F. SPSS and SAS procedures for estimating indirect effects in simple mediation models. Behav. Res. Methods Instrum. Comput. 2004, 36, 717-731. [CrossRef]

55. Alba, J.W.; Hutchinson, J. Dimensions of consumer expertise. J. Consum. Res. 1987, 13, 411-454. [CrossRef]

56. Kumar, A.; Krishnan, S. Memory interference in advertising. J. Consum. Res. 2004, 30, 602-611. [CrossRef]

57. Zinkhan, G.M.; Muderrisoglu, A. Involvement, familiarity cognitive differentiation and advertising recall: A test of convergent and discriminant validity. Adv. Consum. Res. 1985, 12, 356-360.

58. Fazio, R.H.; Zanna, M.P. Direct Experience and Attitude-Behavior Consistency. In Advances in Experimental Social Psychology; Berkowitz, L., Ed.; Academic Press: New York, NY, USA, 1981; Volume 14, pp. 161-202.

59. Gardner, M.P. Advertising effects on attributes recalled and criteria used for brand evaluations. J. Consum. Res. 1983, 10, 310-318. [CrossRef]

60. Roy, R.; Sharma, P. Scarcity appeal in advertising: Exploring the moderating roles of need for uniqueness and message framing. J. Advert. 2015, 44, 349-359. [CrossRef]

61. Boston Consulting Group. Pulse of the Fashion Industry. Available online: http://globalfashionagenda.com/ wp-content/uploads/2017/05/Pulse-of-the-Fashion-Industry_2017.pdf (accessed on 5 January 2020).

62. Mohr, L.A.; Webb, D.J. The effects of corporate social responsibility and price on consumer responses. J. Consum. Aff. 2005, 39, 121-147. [CrossRef]

(C) 2020 by the authors. Licensee MDPI, Basel, Switzerland. This article is an open access article distributed under the terms and conditions of the Creative Commons Attribution (CC BY) license (http://creativecommons.org/licenses/by/4.0/). 